\title{
PEMETAAN SUSEPTIBILITAS MAGNETIK ENDAPAN TANAH SUNGAI SAIL PEKANBARU
}

\author{
Salomo, Danti Oktavia ${ }^{*}$, Usman Malik \\ Jurusan Fisika, Fakultas Matematika dan Ilmu Pengetahuan Alam, Universitas Riau, Kampus Bina Widya \\ J1. Prof. Muchtar Luthfi Pekanbaru, 28293, Indonesia \\ "e-mail: dantioktavia@yahoo.com
}

\begin{abstract}
ABSTRAK
Pemetaan nilai suseptibilitas magnetik endapan tanah di sepanjang sungai Sail Pekanbaru menggunakan Software Surfer 11 telah dilakukan. Sampel terdiri dari 70 titik lokasi yang terdiri dari 35 titik bagian tepi kanan sungai dan 35 titik bagian tepi kiri sungai. Metode pengambilan sampel menggunakan metode grid. Hasil perhitungan tingkat kemagnetan menunjukkan rentang nilai 0,03\% sampai 0,19\%.Hasil pemetaan nilai tingkat kemagnetan menunjukkan bahwa tingkat kemagnetan yang diperoleh semakin tinggi dari hulu ke hilir nya. Hasil perhitungan nilai suseptibilitas magnetik endapan tanah sungai Sail Pekanbaru berkisar antara $0,82 \times 10^{-8} \mathrm{~m}^{3} / \mathrm{kg}$ sampai dengan $3,44 \times 10^{-8} \mathrm{~m}^{3} / \mathrm{kg}$, berdasarkan nilai ini dapat diperkirakan bahwa partikel magnetik utama penyusun sampel di sungai Sail Pekanbaru adalah ilmenit. Hasil pemetaan nilai suseptibilitas magnetik dan suseptibilitas massa menunjukkan bahwa suseptibilitas magnetik di sungai Sail Pekanbaru dari hulu ke hilir nya semakin sedikit.
\end{abstract}

Kata Kunci: Pemetaan; Software Surfer 11; Sungai Sail Pekanbaru; Tingkat Kemagnetan; Suseptibilitas Magnetik

\begin{abstract}
[Title: Mapping Of The Sedimentary Magnetic Susceptibility Of Sail River Pekanbaru] Mapping the value of the sedimentary magnetic susceptibility along the Sail Pekanbaru river using Surfer 11 Software has been carried out. The sample consisted of 70 location points consisting of 35 right bank edges and 35 left bank edges. The sampling method uses the grid method. The results of the magnetic level calculation show a range of values from $0,03 \%$ to $0,19 \%$. The results of magnetic degree value mapping indicate that the magnetic degree obtained is getting higher from upstream to downstream. The results showed that the suseptibility magnetic value of sediment in the Sail Pekanbaru river ranged from $0,82 \times 10^{-8} \mathrm{~m}^{3} / \mathrm{kg}$ to 3,44 $\times 10^{-8} \mathrm{~m}^{3} / \mathrm{kg}$, based on this value it can be estimated that the main magnetic particles of the sample are in the Sail Pekanbaru river is ilmenit. The results of mapping the magnetic susceptibility values and mass susceptibility values of the samples indicate that the magnetic susceptibility in the Sail Pekanbaru river from upstream to downstream is less.
\end{abstract}

Keywords: Mapping, software surfer 11, Sail Pekanbaru river, magnetic degree, magnetic susceptibility

\section{PENDAHULUAN}

Sungai di banyak kota Negara berkembang sering digunakan sebagai saluran pembuangan dalam jumlah besar sehingga menimbulkan limbah antropogenik dalam jumlah yang sangat besar juga. Terlepas dari penyumbatan dasar sungai, limbah juga membawa banyak bentuk polutan seperti logam berat (Dekimpe, 2000).

Tanah yang mengandung logam berat mempunyai nilai suseptibilitas magnetik yang lebih tinggi daripada tanah yang tidak mengandung logam berat karena logam berat termasuk kedalam mineral magnetik yang memiliki nilai suseptibilitas magnetik yang cukup tinggi. Suseptibilitas magnetik adalah ukuran dari kemampuan suatu bahan untuk termagnetisasi (brempong, 2016).

Sungai Sail yang berada dalam wilayah kota pekanbaru merupakan salah satu anak Sungai Siak yang mengalir melewati empat kecamatan yang ada di kota Pekanbaru, yaitu Kecamatan Bukit Raya, Tenayan Raya, Sail dan Lima Puluh. Sungai Sail 
memiliki panjang $\pm 10 \mathrm{~km}$ denganbagian hulu terletak $\pm 200 \mathrm{~m}$ ke arah selatan dari Kecamatan Bukit Raya dan hilirnya terletak di Kecamatan Lima Puluh (BPS Kota Pekanbaru, 2019). Sungai Sail yang berada di kota Pekanbaru digunakan oleh sebagian besar masyarakat untuk berbagai macam keperluan dan disertai dengan aktivitas pembangunan yang semakin pesat menyebabkan banyak limbah yang terdapat pada Sungai Sail. Sifat magnetik dari tanah di tepianSungai Sail dapat diketahui dengan menentukan tingkat kemagnetan dan juga suseptibilitas magnetik yang terkandung dalam tanah menggunakan Probe Magnetic Pasco PS-2162.

Penelitian tentang suseptibilitas magnetik ini telah banyak dilakukan oleh beberapa peneliti seperti pemetaan nilai suseptibilitas magnetik tanah di sekitar kampus universitas riau pekanbaru (Ayuni, 2018), identifikasi pencemaran logam berat dan hubungannya dengan suseptibilitas magnetik pada sedimen sungai batang ombilin kota sawahlunto (putri, 2017), serta magnetic susceptibility as indicator of environmental pullution of soil in tallin (Bityukova, 1999).

Penelitian ini akan menghasilkan peta kontur dari nilai suseptibilitas magnetik endapan tanah di sepanjang Sungai Sail Pekanbaru.

\section{TINJAUAN PUSTAKA}

\section{MEDAN MAGNET}

Daerah disekitar magnet yang masih merasakan adanya gaya magnet disebut medan magnet. Sebatang magnet jika diletakkan dalam suatu ruangan tertentu maka ruangan tersebut akan merasakan adanya medan magnetik yang ditimbulkan oleh magnet tersebut. Kutub magnet adalah daerah yang memiliki rapat flux magnet tertinggi disekitar magnet. Kutub magnet pada suatu magnet batang berada didekat ujung-ujung magnet yang memiliki kuat medan magnet yang paling besar dan garis gayanya rapat. Apabila kutub yang sama didekatkan maka akan terjadi tolakmenolak tetapi sebaliknya apabila kutub yang berlainan didekatkan akan terjadi tarik-menarik. Satuan SI untuk medan magnet adalah Tesla (T) dan total flux magnetik adalah weber $\left(1 \mathrm{Weber} / \mathrm{m}^{2}=1\right.$ Tesla) sedangkan dalam CGS adalah Gauss (G) dimana 1 Tesla $=10^{4}$ Gauss [7].

\section{SOLENOID}

Solenoid merupakan kumparan (koil) yang terbentuk dari susunan kawat berbahan konduktor yang dapat dialiri arus listrik. Kuat medan magnet di dalam solenoid jauh lebih besar dibandingkan dengan kuat medan magnet di luar solenoid. Solenoid disebut ideal apabila medan magnet di dalam solenoida bersifat homogen dan medan magnet diluarnya bernilai nol.

Kuat medan magnet (B) di dalam solenoid dapat dihitung dengan menggunakan Hukum Ampere seperti Persamaan (1).

$$
\int B \cdot d l=B l
$$

Kawat pada solenoid berarus listrik $I_{0}$ jika terdapat Nbuah lilitan pada solenoid sepanjang 1 maka didapat Persamaan (2).

$$
B=\mu_{0} I_{0} \frac{N}{l}
$$

\section{SUSEPTIBILITAS MAGNETIK}

Suseptibilitas magnetik merupakan ukuran kemampuan suatu bahan terhadap pengaruh medan magnetik luar. Pengukuran suseptibilitas memungkinkan kita untuk mengidentifikasi mineral magnetik pembawa Fe dalam suatu sampel. Suseptibilitas

magnetik $\left(\chi_{m}\right)$ didefinisikansebagaiperbandingan antara magnetisasi $(M)$ dengan intensitas magnet (H)yang ditampilkan dalam Persamaan (3).

$$
\chi_{m}=\frac{M}{H}
$$

Suseptibilitas magnetik bahan $\left(\chi_{m}\right)$ dapat ditentukan dengan Persamaan(4).

$$
\chi_{m}=\frac{B_{T}-B_{0}}{B_{0}}
$$

Nilai suseptibilitas magnetik dalam buku teks kebanyakan tidak ditampilkan secara langsung namun nilai ini diberikan dalam bentuk suseptibilitas $\operatorname{massa}\left(\chi_{m, \text { massa }}\right)[8]$ sepertiPersamaan (5) 


$$
\chi_{m, m a s s}=\frac{\chi_{m}}{\rho}
$$

\section{TINGKAT KEMAGNETAN}

Bahan magnetik merupakan bahan yang memiliki sifat kemagnetan dalam komponen pembentuknya. Bahan tersebut tersusun dari atomatom yang terdiri dari elektron yang dapat bergerak dalam suatu atom tunggal sehingga menghasilkan arus yang disebut arus atom. Nilai tingkat kemagnetan dapat ditentukan dengan menggunakan Persamaan (4).

$$
\mathrm{M}_{\mathrm{D}}=\frac{m_{k}}{m_{s}} \times 100 \%
$$

\section{SOFTWARE SURFER}

Pemetaan nilai suseptibilitas magnetik dari endapan tanah dapat dilakukan dengan menggunakan softwareSurfer. Surfer merupakan salah satu perangkat lunak yang digunakan untuk pembuatan peta kontur berdasarkan pada grid. Perangkat lunak ini melakukan Plotting data tabular XYZ tak beraturan menjadi lembar titik-titik segi empat (grid) yang beraturan. Grid adalah serangkaian garis vertikal dan horizontal yang dalam Surfer berbentuk segi empat yang digunakan sebagai dasar pembentuk kontur. Gridding merupakan proses pembentukan rangkaian nilai $Z$ dari sebuah data XYZ. Hasil dari proses Gridding ini adalah file grid yang tersimpan pada file.grd.

\section{METODE PENELITIAN}

Pengambilan sampel pada penelitian ini diambil di bawah Jembatan Sail H. Imam Munandar, Tengkerang Labuai, Kota Pekanbaru, Riau. Endapan tanah merupakan sampel pada penelitian ini yang berada di tepianSungaiSail. Sungai Sail berada pada koordinat $0^{\circ} 29^{\prime} 56.1^{\prime \prime N} \quad 101^{\circ} 28^{\prime} 50.2^{\prime \prime E}$. Proses pengambilan sampel dilaksanakan pada bulan Desember 2018. Lokasi penelitian dimulai dari bagian bawah Jembatan Sail H. Imam Munandar, Tengkerang Labuai, Kota Pekanbaru, Riau hingga mencapai titik lokasi sepanjang $700 \mathrm{~m}$.

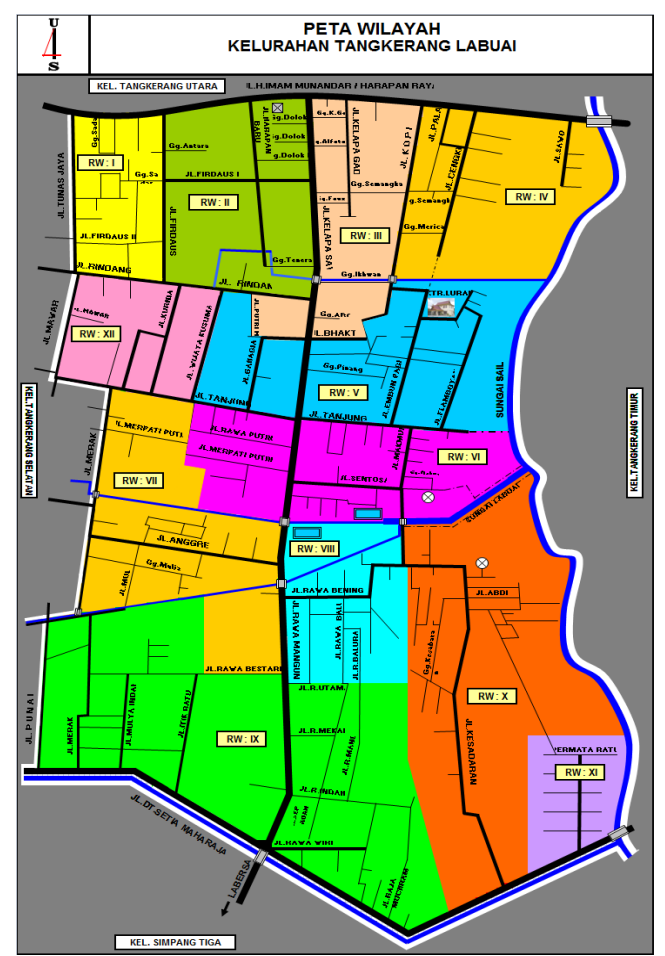

Gambar 1. Lokasi penelitian

Sampel tersebut diambil secara horizontal mengikuti aliran sungai sebanyak 70 titik yang dibagi menjadi 35 titik disebelah kanan tepian sungai dan 35 titik disebelah kiri tepian sungai. Jarak setiap titik lokasi sampeladalah $20 \mathrm{~m}$ dengan massa tanah yang diambil pada masing-masing lokasi sampelyaitu 0,5 $\mathrm{kg}$. Sampel ini kemudian dijemur dibawah sinar matahari selama 1 sampai 2 hari. Sampel yang telah kering kemudian di saring menggunakan ayakan untuk dibersihkan dari sampah dan batuan. 


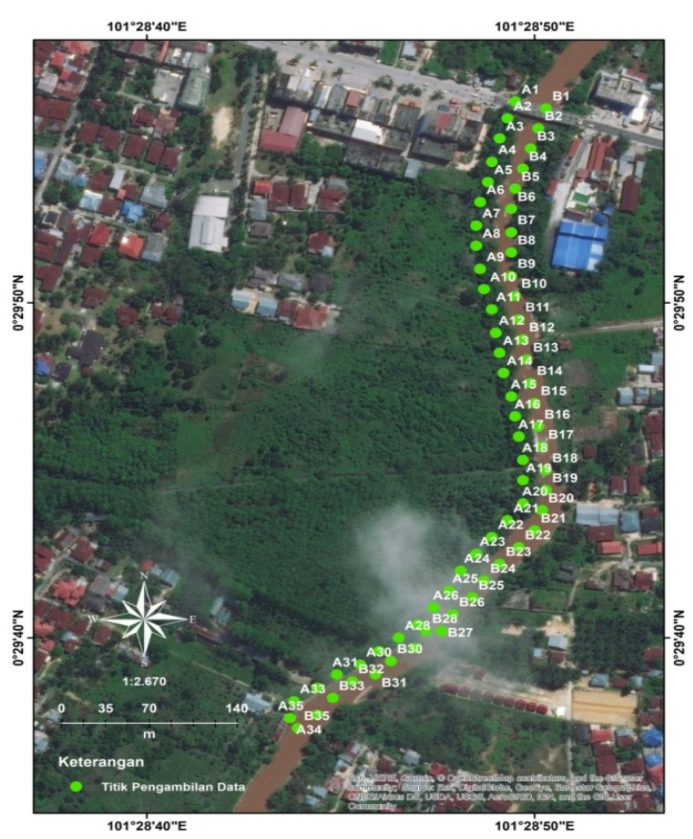

Gambar 2.Pengambilan sampel menggunaan metode grid

Pemisahan konsentrat dilakukan dengan menggunakan magnet batang Neodibium Iron Boron (magnet batang). Pengukuran pada solenoid tanpa inti $\left(\mathrm{B}_{0}\right)$ diawali dengan pengukuran induksi magnetik sebagai fungsi arus $(2,4,6,8)$ A dengan jarak tetap (1 mm) dan fungsi jarak $(1,2,3,4$, 5)mmdenganarus tetap (2 A) menggunakan Probe Magnetic Pasco PS-2162yang tersambung dengan Software Data Studio.

Pengukuran induksi magnetik dengan inti sampel dilakukan dengan cara solenoid diisi dengan sampel sebanyak $5 \mathrm{~mL}$ dan diratakan permukaannyakemudian solenoid dihubungkan dengan Power Supply. Probe Magnetic Pasco-2162 digunakan untuk mengukur nilai induksi magnetik dari sampel tersebut yang telah tersambung dengan Software Data Studio pada laptop. Pengukuran induksi magnetik dengan inti konsentrat dilakukan dengan cara solenoid diisi dengan konsentrat yang didapatkan dari pemisahan konsentrat dengan endapan tanah menggunakan Neodibium Iron Boron (magnet batang) dan diratakan permukaannya kemudian solenoid dihubungkan dengan Power Supply. Probe Magnetic Pasco-2162 digunakan untuk mengukur nilai induksi magnetik dari konsentrat tersebut yang telah tersambung dengan SoftwareData Studio pada laptop.
Peta kontur massa konsentrat, tingkat kemagnetan, suseptibilitas magnetik dan suseptibilitas massa dibuat dengan menggunakan Software "Surfer 11". SoftwareSurfer merupakan salah satu perangkat lunak yang digunakan untuk pembuatan peta kontur berdasarkan metode grid. Data yang digunakan untuk pembuatan peta kontur adalah data titik koordinat dari masing-masing sampel serta data massa konsentrat, tingkat kemagnetan, suseptibilitas magnetik dan suseptibilitas massa dari masing-masing sampel. Peta kontur ini digunakan sebagai sarana untuk memonitor dan memetakan daerah yang digunakan dalam penelitian ini.

\section{HASIL DAN PEMBAHASAN}

Nilai tingkat kemagnetan didapat dengan membandingkan massa konsentrat dan massa sampel $\left(m_{k}: m_{s}\right)$. Massa konsentrat didapat dari proses pemisahan konsentrat tanah dengan menggunakan magnet batang Neodibium Iron Boron di 70 titik sampel disatu lokasi pengambilan sampel yaitu di sungai Sail Pekanbaru.

Peta kontur didapatkan dari nilai massa konsentrat dan tingkat kemagnetan yang di input pada program komputer yaitu "Software Surfer 11" sebagai sumbu Z dan koordinat Bujur Timur sebagai sumbu $X$ serta koordinat lintang utara sebagai sumbu Y.

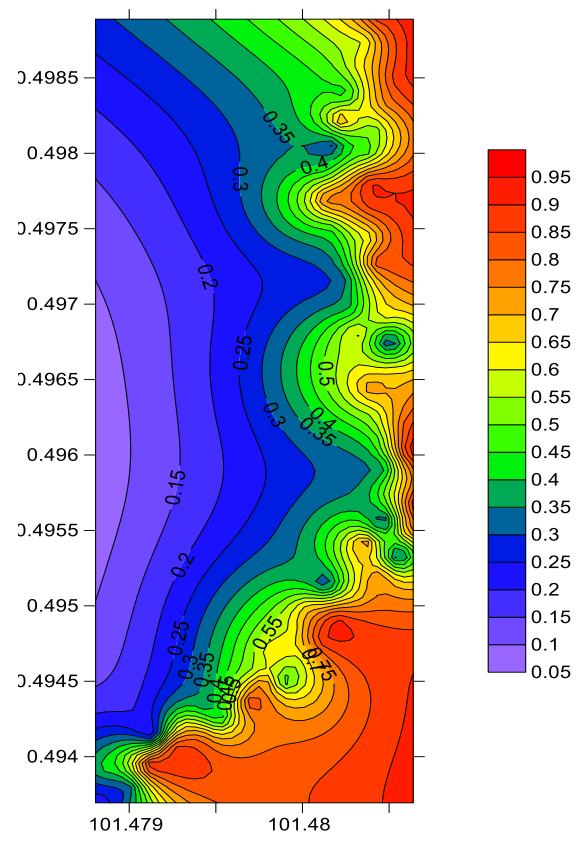

Gambar 3. Massa konsentrat 


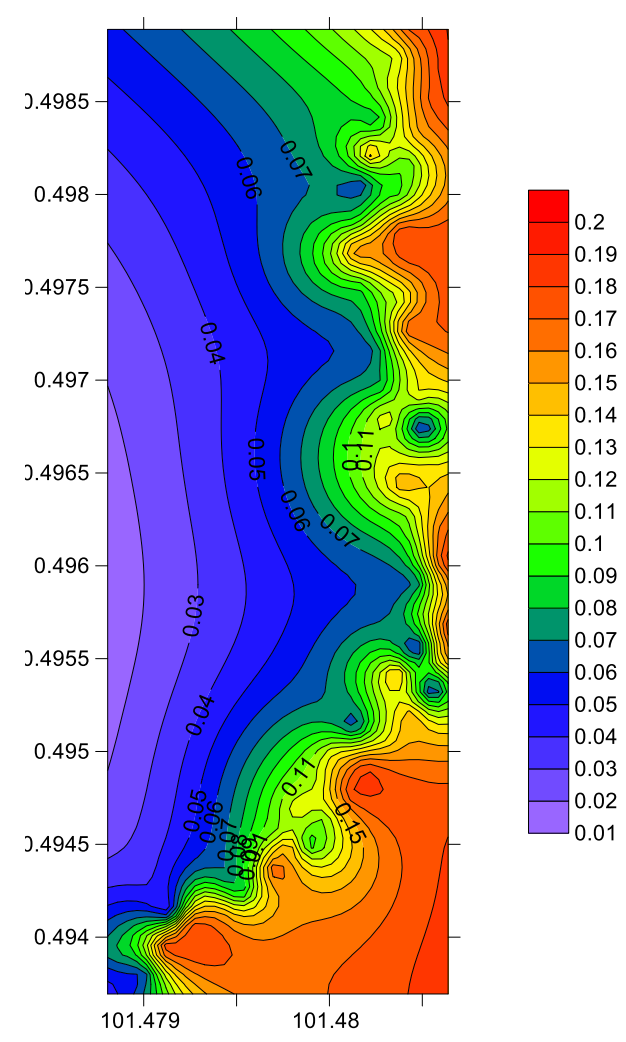

Gambar 4. Tingkat kemagnetan

Gambar 3 dan 4 menunjukkan bahwa nilai massa konsentrat dan tingkat kemagnetan yang didapat dari hasil penelitian di Sungai Sail Pekanbaru semakin meningkat. Nilai massa konsentrat dan tingkat kemagnetan tertinggi pada peta kontur ada pada skema warna merah dan nilai terendah ada pada skema warna ungu tetapi dari hasil penelitian yang dilakukan nilai massa konsentrat dan tingkat kemagnetan yang didapat berada pada rentang skema warna orange dengan nilai tertinggi dan rentang skema warna biru dengan nilai terendah. Skema warna orange pada peta kontur massa konsentrat berada pada interval $(0,9-0,95) \mathrm{g}$ dan hasil penelitian didapat massa konsentrat yaitu 0,93 g sedangkan skema warna biru pada peta kontur berada pada interval $(0,15$ - 0,2) g dan hasil penelitian didapat massa konsentrat yaitu 0,16 g. Skema warna orange pada tingkat kemagnetan pada peta kontur berada pada interval $(0,19-0,2) \%$ dan hasil penelitian didapat nilai tingkat kemagnetan yaitu 0,19\%, tinggi nya tingkat kemagnetan disebabkan oleh titik sampel yang berada dibawah jembatan dengan kontribusi partikel gas buang kendaraan bermotor yang terbawa oleh angin jatuh ke sungai dan partikel tersebut ada yang mengendap di tanah sungai dan ada juga terbawa oleh air sungai yang mengalir. Skema warna biru pada peta kontur berada pada interval $(0,03-0,04) \%$ dan hasil penelitian didapat nilai tingkat kemagnetan yaitu $0,03 \%$, rendahnya nilai tingkat kemagnetan disebabkan oleh sampel diambil didaerah pemukiman penduduk yang diduga limbah yang dihasilkan dari limbah rumah rumah tangga tidak banyak mengandung mineral magnetik. Perbedaan nilai tingkat kemagnetan juga dipengaruhi oleh cuaca pada saat pengambilan sampel yang berubahubah menyebabkan titik-titik lokasi ada yang terendam air sungai dan ada yang tidak terendam air sungai. Peta kontur menunjukkan bahwa massa konsentrat dan tingkat kemagnetan dari hasil penelitian di sungai Sail Pekanbaru dari hulu ke hilir nya yaitu semakin tinggi.

Gambar 5 dan 6 merupakan peta kontur dari nilai suseptibilitas magnetik dan suseptibilitas massa yang di input pada program komputer yaitu “Software Surfer 11" sebagai sumbu Z dan koordinat Bujur Timur sebagai sumbu X serta koordinat lintang utara sebagai sumbu Y.

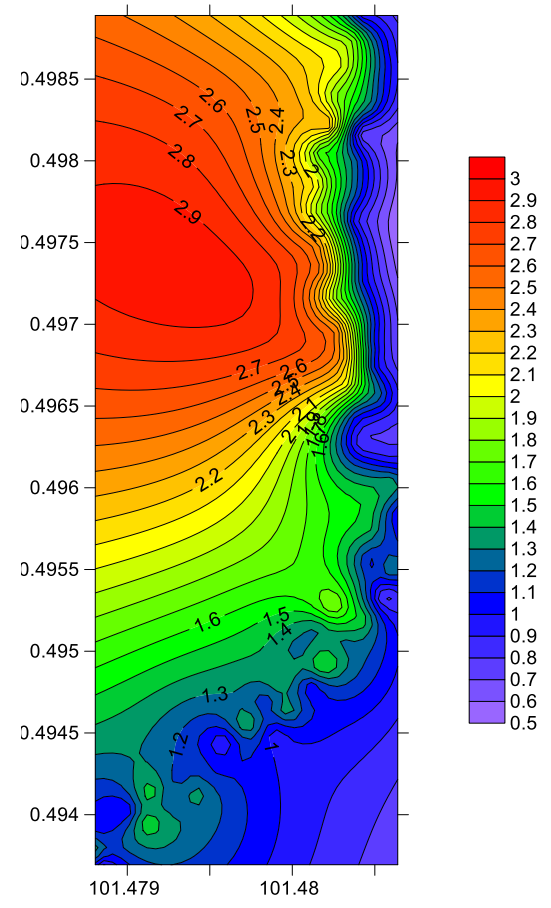

Gambar 5. Peta kontur suseptibilitas magnetik 


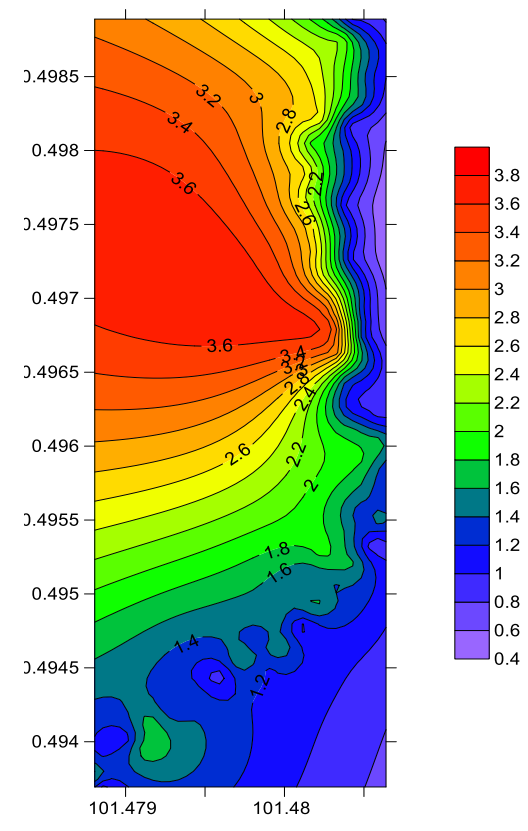

Gambar 6. Peta kontur suseptibilitas massa

Gambar 5dan Gambar 6 menjelaskan bahwa nilai suseptibilitas magnetik dan suseptibilitas massa yang didapat dari hasil penelitian di sungai Sail Pekanbaru semakin menurun. Nilai suseptibilitas magnetik dan suseptibilitas massa tertinggi pada peta kontur ada pada skema warna merah dan nilai terendah ada pada skema warna ungu tetapi dari hasil penelitian yang dilakukan nilai suseptibilitas magnetik dan suseptibilitas massa yang didapat berada pada rentang skema warna orange dengan nilai tertinggi dan rentang skema warna biru dengan nilai terendah. Skema warna orange pada peta kontur suseptibilitas magnetik berada pada interval $(2,4-2,5) \times 10^{-5}$ dan hasil penelitian didapat nilai suseptibilitas magnetik yaitu $2,46 \times 10^{-5}$ sedangkan skema warna biru pada peta kontur berada pada interval $(0,7-0,8) \times 10^{-5}$ dan hasil penelitian didapat nilai suseptibilitas magnetik yaitu 0,71 $\times 10^{5}$. Skema warna orange pada suseptibilitas massa pada peta kontur berada pada interval $(3,4-3,6)$ $\times 10^{-8} \mathrm{~m}^{3} / \mathrm{kg}$ dan hasil penelitian didapat nilai suseptibilitas massa yaitu $3,44 \times 10^{-8} \mathrm{~m}^{3} / \mathrm{kg}$ sedangkan skema warna biru pada peta kontur berada pada interval $(0,8-1) \times 10^{-8} \mathrm{~m}^{3} / \mathrm{kg}$ dan dari hasil penelitian didapat nilai suseptibilitas massa yaitu $0,82 \times 10^{-8} \mathrm{~m}^{3} / \mathrm{kg}$. Nilai suseptibilitas magnetik dan suseptibilitas massa dari masing-masing sampel berbeda tergantung pada kuat medan dari sampel tersebut.Perbedaan nilai suseptibilitas magnetik dan suseptibilitas massa ini disebabkan adanya perbedaan kuantitas mineral magnetik dalam endapan tanah. Peta kontur menunjukkan bahwa suseptibilitas magnetik dan suseptibilitas massa dari hasil penelitian di sungai Sail Pekanbaru dari hulu ke hilir nya semakin sedikit.

\section{KESIMPULAN}

Berdasarkan hasil penelitian yang telah dilakukan maka dapat diambil kesimpulan bahwatingkat kemagnetan tertinggi dari pengambilan sampel di Sungai Sail Pekanbaru dengan nilai $0,19 \%$ dan tingkat kemagnetan terendah dengan nilai $0,03 \%$. Tinggi nya tingkat kemagnetan disebabkan oleh kontribusi partikel gas buang kendaraan bermotor yang melewati jembatan terbawa oleh angin jatuh ke sungai dan partikel tersebut ada yang mengendap di tanah sungai dan ada juga terbawa oleh air sungai yang mengalir. Rendahnya nilai tingkat kemagnetan disebabkan oleh sampel diambil didaerah pemukiman penduduk yang diduga limbah yang dihasilkan dari limbah rumah rumah tangga tidak banyak mengandung mineral magnetik. Peta kontur menunjukkan bahwa massa konsentrat dan tingkat kemagnetan dari hasil penelitian di sungai Sail Pekanbaru dari hulu ke hilir nya yaitu semakin tinggi. Nilai suseptibilitas yang diperoleh dari masing-masing sampel di sungai Sail Pekanbaru berada pada interval nilai suseptibilitas magnetik ilmenite yaitu $\left(46 \times 10^{-8} \mathrm{~m}^{3} / \mathrm{kg}-80000\right.$ $\mathrm{x} 10^{-8} \mathrm{~m}^{3} / \mathrm{kg}$ ) yang berarti bahwa masing-masing sampel mengandung partikel ilmenite.Peta kontur yang dihasilkan menunjukkan bahwa suseptibilitas magnetik di sungai Sail Pekanbaru dari hulu ke hilir nya yaitu semakin sedikit.

\section{DAFTAR PUSTAKA}

Afni, Fauzi. 2018. Pemetaan Suseptibilitas Magnetik Pasir Dan Debu Di Km 6 JalanGaruda Sakti Pekanbaru Dengan Menggunakan Software Surfer, Skripsi Jurusan Fisika FMIPA, Universitas Riau, Pekanbaru.

Ayuni, Sonia. 2018. Pemetaan Nilai Suseptibilitas Magnetik Tanah Di SekitarKampus Universitas Riau Pekanbaru, Skripsi 
Jurusan Fisika FMIPA, Universitas Riau, Pekanbaru.

Badan Pusat Statistik Kota Pekanbaru. 2009.

Pekanbaru Dalam Angka. Badan

Perencanaan Pembangunan Daerah

Pekanbaru Bekerjasama dengan Badan

Pusat Statistik Kota Pekanbaru.

Pekanbaru. 121 hal (tidak diterbitkan).

Brempong, F., Mariam, Q., dan Preko, K. 2016.

The Use of Magnetic Susceptibility Measurements to Determine Pollution of Agricultural Soils in Road Proximity. African Journal of Environmental Science and Technology: Vol. X, 2016. (263-271).

Bityukova, L. R. Scholger., dan M, Birke. 1999. Magnetic Susceptibility as Indicator of Environmental Pollution of Soils in Tallinn. Elsevier Science: Vol. XXIV, No. 9, 1999. (829-835).

DeKimpe, C. R., dan Morel, J. L. 2000. Urbansoil Management a growing concern. Soil Science: Vol. CLXV, No. 1, 2000. (31-40).

Putri, Dian., dan Afdal. 2017. Identifikasi Pencemaran Logam Berat dan Hubungannya dengan Suseptibilitas Magnetik pada Sedimen Sungai Batang Ombilin Kota Sawahlunto. Jurnal Fisika Unand. Vol. VI, No. 4,2017.

Young, Hugh., dan Roger, A. Freedman. 2003. Fisika Universitas (Terjemahan) Jilid1. Jakarta: Erlangga. 